\title{
King Abdulaziz University Approach to Develop Financial Resources
}

\author{
Abdulrahman Obaid Al-Youbi \\ and Adnan Hamza Mohammad Zahed
}

\section{Introduction}

Saudi universities have benefited a lot from the budgets provided by the government to universities in order to encourage education and spread it among the various groups of Saudi society. While many universities around the world depend, as part of their budget, on the university fees collected from students, in addition to the support provided by their governments, the public universities in Saudi Arabia, since their establishment, provide education to their students free. Furthermore, they give their students financial grants covering their personal expenses, based on the Kingdom of Saudi Arabia's policy of building a welfare state for all members of society. In addition to supporting university education, the generous budget received by Saudi universities also supports graduate studies, scientific research, laboratory equipment, infrastructure preparation, and the construction of modern buildings through dedicated budgets. The Saudi education policies have served their purpose and paid off, as several Saudi universities have been qualified to occupy distinguished ranks in the international rankings of world universities, gaining popularity with each occupying a prominent position among their counterparts around the world [1-3].

Beginning of planning for a promising future, the Saudi Vision 2030 is built around three main themes and based on three pillars, namely: (a vibrant society, a thriving economy and an ambitious nation); these pillars are complementary and consistent with each other in order to achieve the goals of the Vision and maximize the use of its foundations. In the pillar of (a thriving economy), the Saudi Vision focuses, among others, on diversifying the economy, allocating

A. O. AI-Youbi

President of King Abdulaziz University, King Abdulaziz University, Jeddah, Saudi Arabia

A. H. M. Zahed ( $\bowtie)$

Secretary-General of the International Advisory Board, King

Abdulaziz University, Jeddah, Saudi Arabia

e-mail: iab@kau.edu.sa government services, achieving balance in the budget, diversifying and maximizing revenue sources, and managing the public budget in a rational manner, while committing to raising the efficiency of public expenditure, achieving efficiency in the use of resources, reducing waste and increasing non-oil government revenues [4].

Based on the Saudi Vision, various parties developed their visions, and the new Saudi universities by-law has been issued at the beginning of 2020. This by-law allowed universities to establish their own endowments, it also allowed the universities and their endowments to establish companies, participate in their establishment or join them as a partner or shareholder. The new Saudi universities by-law also specified the university's revenues from the state subsidy; the cost of the study programs, diplomas, courses, and services provided; donations, gifts, grants, and wills, provided that their terms and purposes are consistent with the university's mission; the return on its properties; the investment of university facilities; its own revenues and endowments; and the financial resources approved by the university's board of trustees, which do not conflict with the university's goals, vision, and mission. The new Saudi universities by-law also allows the university to charge tuition fees for graduate studies programs; diploma and educational and training courses programs; tuition fees from non-Saudi students; as well as sums of money in exchange for scientific research or consulting services for internal or external parties; and sums of money in exchange for contracting with other parties in both public and private sectors to provide the staff members that these parties need or to undertake studies, services and consultations [5].

As is well known, universities play a critical role in the life of nations at different stages of their economic and social development, as their contributions extended to include all aspects of scientific and technical life. This made interacting with society to discuss its needs and provide its requirements one of the most important duties of universities today. There is no doubt that one of the most important requirements of 


\section{Deanship of Community Services \\ and Continuing Education}

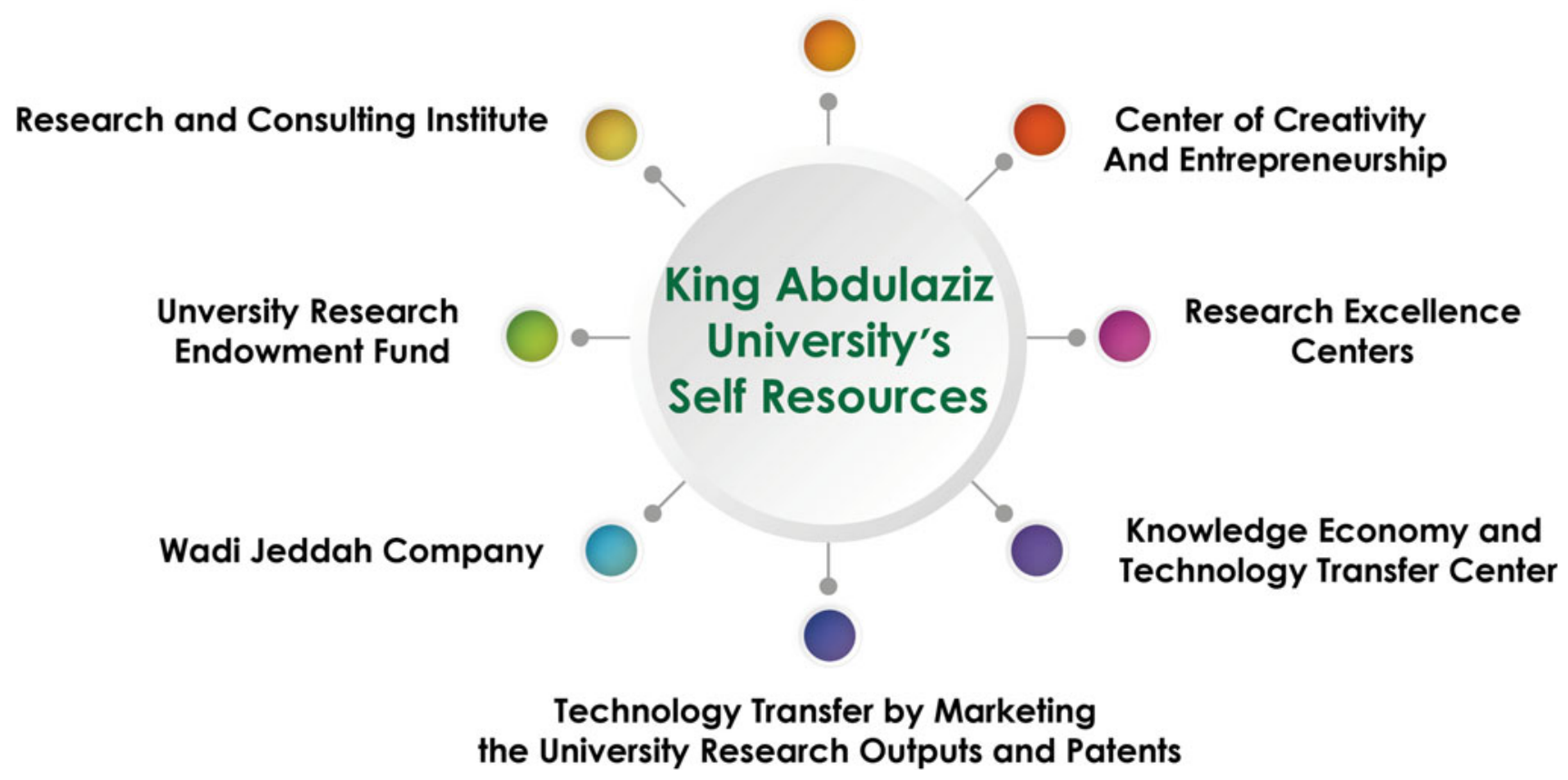

Fig. 1 KAU's self resources

society is to reach high ranks in scientific research, to gain access to technology innovation, work to localize it, and increase social awareness. This can only be achieved through increasing funding to spend on education and scientific research. In the spirit of providing the necessary funding for conducting scientific research and revitalizing scientific research in basic and applied sciences. Saudi universities, through the new by-law, have achieved a large degree of independence allowing them to work on diversifying their sources of income. On these bases, King Abdulaziz University, throughout its career, especially in the first two decades of the twenty-first century, has taken many steps that increase the sources of income and develop its financial resources. In this (first) chapter, King Abdulaziz University's approach to developing its financial resources is presented.

\section{The Current Status of KAU, Its Financial Resources, and Its Need for Other Resources}

The number of students at KAU in the academic year of $2019 / 2020$ is $(79,643)$ students, who all receive scholarships, and it employs about $(19,000)$ male and female employees of both sexes, including (7569) faculty members and their assistants from the academic staff.

KAU receives an annual budget of about (1.3) billion dollars from the government, while the university's own income sources amount to (0.21) billion dollars, which is equivalent to $16 \%$ of the university's total budget. In addition to government funding, there are some resources that the university has worked on to increase its budget, depending on its own potential. Figure 1 shows the resources of King Abdulaziz University's self resources.

\section{Investment Management in KAU}

Investment units were established at KAU in the University Vice Presidency for Projects, Deanship of Student Affairs, and Contracts and Procurement Management at various times as needed. The Investment Management was then established in 2017 to include all investment units, and to organize the investment of real estate and university facilities. The Investment Management aims at studying, increasing and developing investment of real estate and university facilities in a way that contributes to increasing revenues and achieving financial self resources from the university's properties, while raising the efficiency and improving the level of performance of the university's investment projects; in addition to finding investment opportunities for university facilities for the private sector and contributing to improving the level of services provided by the university to the community [6]. 


\section{General Administration for Self Resources}

Based on the goals of the university and its scientific mission in disseminating culture, knowledge, as well as scientific, cultural and technical awareness among various sectors of society through the university's academic departments, which abound with distinguished faculty members in various disciplines and advanced scientific capabilities, the university provided paid services to all societal groups through the Deanship of Community Services and Continuing Education and the Deanship of Research and Consulting Institute. In light of the increasing growth of paid educational programs and research and consulting services provided by the university to the community, the university established an independent administration called (the General Administration for Self-finance) in 2003, to manage the funding that the university receives other than its allocations in the state budget, Such as grants and wills, the proceeds of investing in university properties, and the revenues resulting from providing educational services, research projects and studies to other parties. In 2016, the name (General Administration for Self-finance) has been changed to (General Administration for Self Resources) and it is linked to the university vice president for business and knowledge creativity. It also supervises the revenues and expenses of self-funded programs independently of the university's financial management [7]. The goals of this administration include developing cooperation and interaction frameworks between KAU and the public and private sectors in the Kingdom in accordance with the general frameworks of the policy, vision, mission and goals of KAU, through the university's general strategic plan. It also seeks to increase the university self resources using the available means, in order to finance university projects and coordinate in this respect with the relevant parties with regard to organizing financial expenses for all self-resource programs; in addition to making the most of self-revenue in the development of the educational and research process in line with the university's strategic plan.

\section{The Deanship of Community Services and Continuing Education}

The Deanship of Community Service \& Continuing Education was established at King Abdulaziz University [8] to be the link between the community and the university to introduce the community to the many capabilities of the university so that the surrounding community can benefit from them. The Deanship offers several programs to the community on a commercial investment basis at competitive prices. These include specialized diploma programs and targeted training courses. It also provides free services to the community through educational lectures and other community activities, the most important of which is hosting the famous TEDx program $[9,10]$ in the university, which is organized by the Deanship to provide an inspiring opportunity for people to expand their horizons and achieve their hopes, by building a culture of creativity and cross-pollination of new and creative ideas worth spreading.

\section{Research and Consulting Institute (RACI)}

The Research and Consulting Institute (RACI) was established in 1997 to be a window for KAU in dealing with the public and private sectors with regard to providing specialized consultations and conducting studies, in addition to other scientific services, in exchange for a financial return for the university [11]. The institute's vision states that the first choice must be at the Gulf level in carrying out research projects and consulting studies with high quality. It aims at working as an advisory expertise house, publicizing the research and advisory capabilities of the university, assisting the service and industrial sectors in developing their performance through studies and consultations, harnessing the potential of KAU to serve the community, enhancing cooperation between KSU and public and private sectors institutions in the field of consulting and research, and benefiting from the public and private sectors in funding research and scientific studies, and providing new sources of income for the university. The Research and Consulting Institute is distinguished by the presence of a broad base of academic staff at KAU, including more than 7500 doctoral experts, with qualifications from the finest American, European and international universities, and specialized in more than 200 scientific disciplines. This is in addition to research assistants, specialized technicians and graduate students. The institute relies, in providing its services, on the infrastructure of KAU with its various 28 colleges, along with 5 institutes, its scientific departments, its specialized 28 research centers, its laboratories that are equipped with modern scientific devices, and its libraries that are linked to global information databases and its information systems that depend on an advanced IT base. The Institute's most important fields of operation include: Expertise Houses, Scientific Chairs, Central Laboratories, Contractual Research, consulting, educational and academic supervision and training. Figure 2 shows the types of services provided by the Research and Consulting Institute, followed by an overview of each of these services.

\subsection{Scientific Chairs}

The scientific chair is a research or academic program at KAU, aimed at enriching human knowledge, developing 


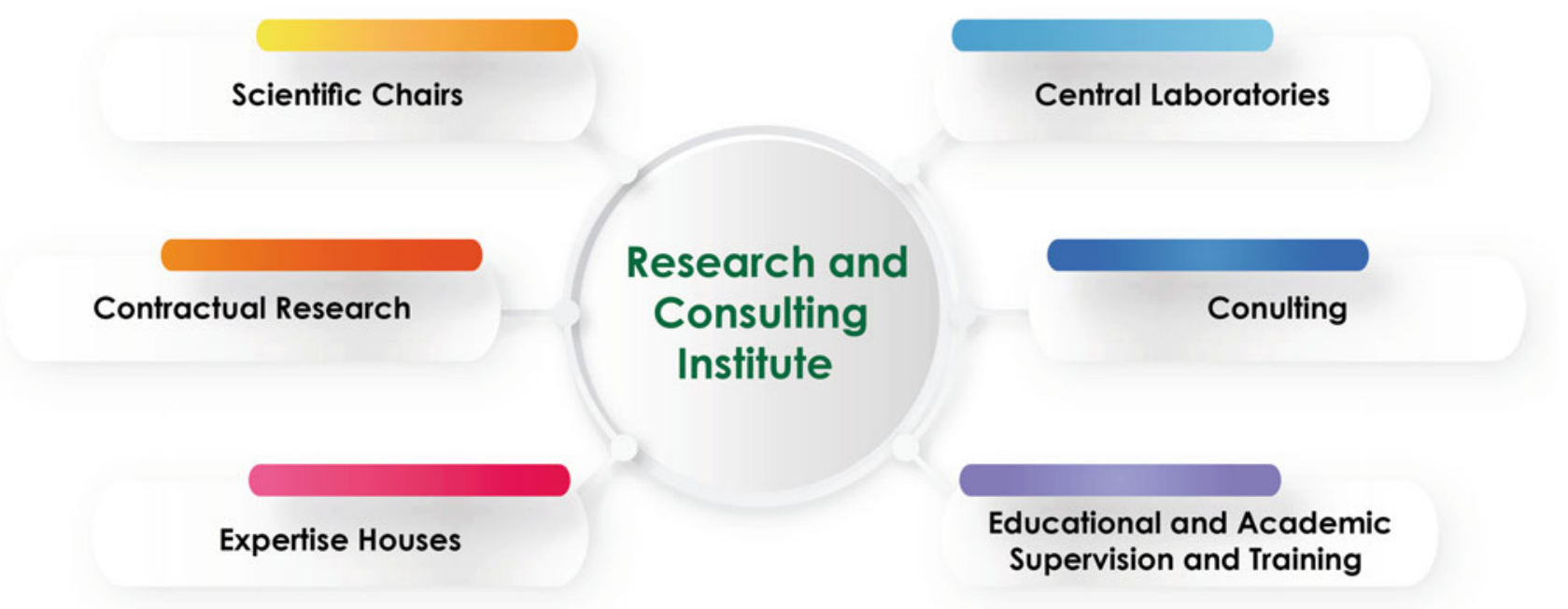

Fig. 2 The types of services provided by the Research and Consulting Institute

thought, and serving local development issues. It is funded by a permanent or temporary cash grant donated by an individual, institution, company, or legal person. One of the specialized professors known for their scientific excellence, leading experience and international reputation is appointed as its supervisor. A team of qualified researchers with competence and experience in the field of the program works within it, and KAU scientific chairs aim at: disseminating the culture of excellence, creativity, innovation and development; supporting KAU and the Kingdom's position in the map of scientific excellence, research, development and knowledge enrichment; transferring and localizing technology, stimulating it with regards to the support of industry, production and services and raising its efficiency; developing partnership ways between KAU and community institutions; increasing the use of human competencies and resources, facilities and equipment in KAU to serve the community; producing outstanding scientific research; supporting graduate studies programs; and obtaining financial support for spending on scientific research. King Abdulaziz University has started establishing of scientific chairs since 2004, and the number has now reached 36 internal and external scientific chairs, which are still ongoing, in addition to the scientific chairs that have been funded for a few years.

\subsection{Central Laboratories}

Central Laboratories at King Abdulaziz University do not belong to a specific college, but rather follow the Knowledge and Business Alliance, and provide their services on an investment basis at competitive prices with high quality to be one of the contributors to KAU financial resources. One of the objectives of the central laboratories is to provide scientific and practical solutions for community institutions in the fields of calibration, analysis and tests, and to interpret them according to the latest international professional specifications, as they invest in the distinguished laboratories in KAU, as well as the experiences of its staff members and technicians, while providing the appropriate environment and administrative, scientific, legal and organizational requirements to activate these potentials. The central laboratories place among their priorities the achievement of excellence and leadership in the fields of calibration laboratory tests and analysis, taking advantage of the laboratories, modern equipment and human expertise they possess. KAU provides these services to the public and private sectors, as the central laboratories cover engineering, environmental, chemical, physical, food and medical fields.

\subsection{Contractual Researches}

The Research and Consulting Institute provides scientific and applied research as to the public and private sectors on a contractual investment basis. Through the human and technical capabilities of KAU, the Institute contributes to finding innovative solutions to various problems of industry and other sectors. Through this service, the Institute contributed to providing scientific solutions and applied studies in various medical, engineering, educational, technical, environmental, social, economic, humanitarian, legal, and urban planning areas...

\subsection{Consultations}

The Research and Consulting Institute provides the consulting expertise of the staff Members at King Abdulaziz 
University to many government and private sectors, on a contractual investment basis. Hundreds of consultations have been provided to various sectors, which reflects the community's eagerness to make use of KAU consulting services due to its distinct benefit represented in the expertise of university faculty. The procedures for requesting consultations have been facilitated in order to speed up the work with flexible and easy procedures.

\subsection{Educational, Academic and Training Supervision}

There is an increasing growth in the private education sector in the Kingdom, as emerging schools, institutes, colleges, and universities are established in various regions. All of these need a neutral academic body to supervise their curricula in order to increase community confidence in them. So they ask universities to supervise the curricula. Here, the Research and Consulting Institute acts as a mediator between the educational bodies requesting the service and the relevant college in KAU to provide the required educational and academic services such as using KAU curricula, supervising teaching and educational processes, and curricula evaluation and arbitration services. These services also include field visits to inspect equipment and laboratories, and supervising exams.

\subsection{Expertise Houses}

The Expertise House is a specialized institution, within $\mathrm{KAU}$, established by a member or group of faculty with close or complementary disciplines, to provide consulting and research services and studies to the public and private sectors in various scientific, practical or theoretical fields through studies, consultations, and implementation of contractual projects, to give the faculty an opportunity to provide services to the community for financial returns, and to invest in and develop the capabilities and potential of various university resources. This in turn enhances the university's role in community service, and allows the different sectors of society to benefit from the expertise of the university faculty. The Research and Consulting Institute provides the administrative, scientific, legal, and organizational requirements necessary for faculty to establish expertise houses, in addition to providing the appropriate headquarters to work from, and in exchange, the university obtains a percentage of the returns on contracts between the expertise houses and parties outside the university.

\section{KAU Research Endowment Fund}

King Abdulaziz University Research Endowment Fund is a modern Islamic economic and charitable system that invests in various assets and directs its returns towards supporting research projects and financing scientific and applied studies and special programs that serve the community and address its economic, scientific, social, health and environmental problems according to the determined research priorities [11].

The endowment generally has a prominent role in the history of Islamic civilization, as the scientific renaissance depended on it. It provided scientists and students of science with a stable climate, and a stable and sustainable resource. This gave Muslim scholars a kind of freedom of research, so they devoted themselves to scientific production, which resulted in this rich heritage of knowledge in various areas.

Providing a fundamental basis for scientific research, today, needs huge allocations, whether to equip laboratories with the latest scientific devices and equipment, or to create a specialized library that relies on regular communication technologies with specialized databases in various scientific fields.

KAU Research Endowment Fund was established in 2005, and it started implementing one of its main tasks in the field of scientific research since 2010.

The objectives of Research Endowment Fund are summarized in several items: Reviving the Islamic Endowment tradition, supporting the applied scientific research needed by the Kingdom, supporting scientific innovations that benefit the country, supporting training, education and cultivation programs, supporting initiatives and activities aimed at developing society, and contributing to the development of the endowment industry in the Kingdom.

The University Endowment Fund has so far adopted a number of initiatives, such as: (Initiative for Supporting Applied Scientific Research), (Initiative of the "Creators" Center for Studies and Research), (Initiative for Sponsoring Scientific Conferences), (Scholarships Initiative), (The Genius Scholars Initiative), ("We Search" Initiative for Undergraduate Students), (Initiative of Graduate Students), ("Horizons" Initiative for Student Clubs), (The Endowment "Research Centers Complex" Initiative), as shown in Fig. 3.

There are several ways to support KAU Research Endowment Fund, such as in-kind donations (land, real estate, property... etc.), cash donations, and monthly deductions from university employees and students provided by donors through permanent orders from their bank accounts. It can also be supported in other ways such as contributing with science, experience and time, free of charge. Figure 4 shows the ways to support the University Research Endowment Fund. 


\section{University Research Endowment Fund Initiatives}

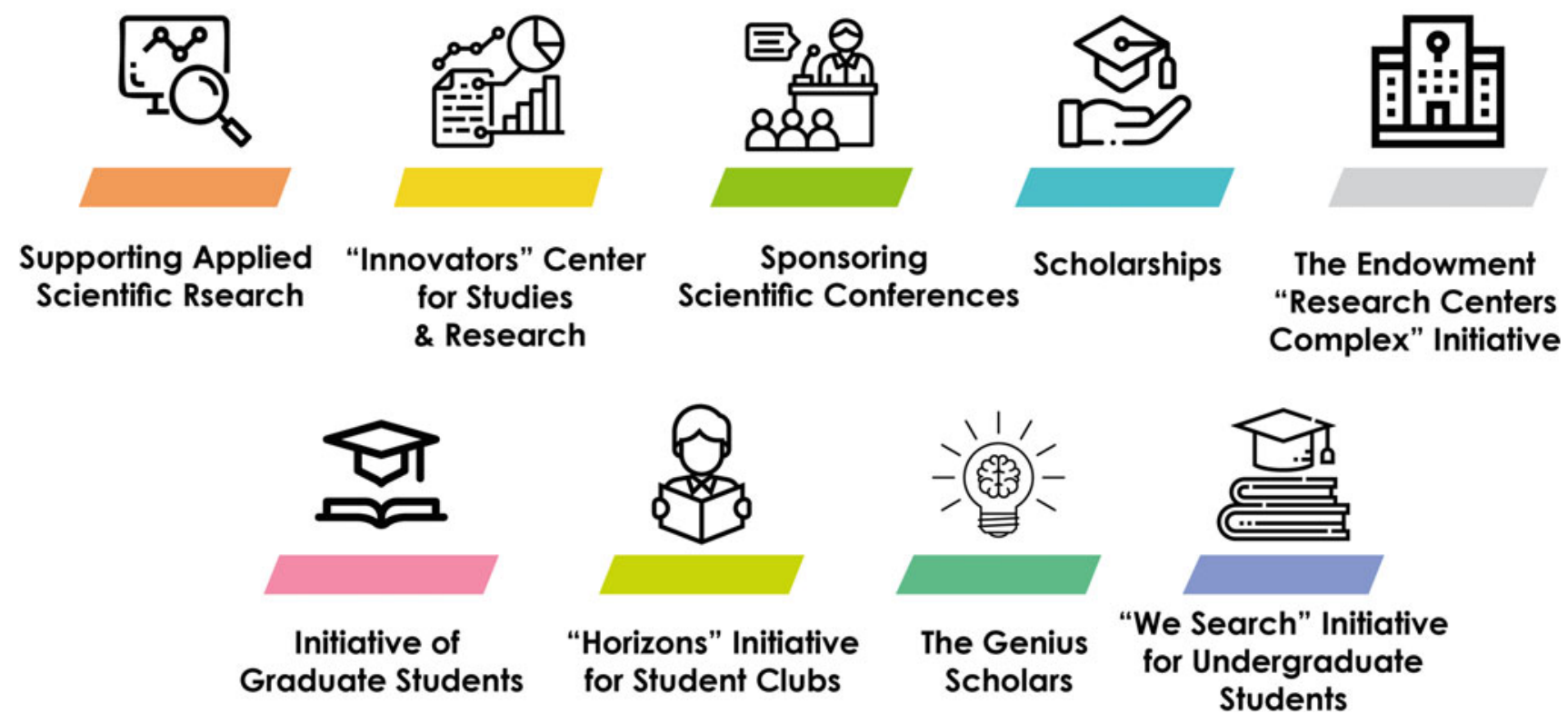

Fig. 3 KAU Research Endowment Fund Initiatives

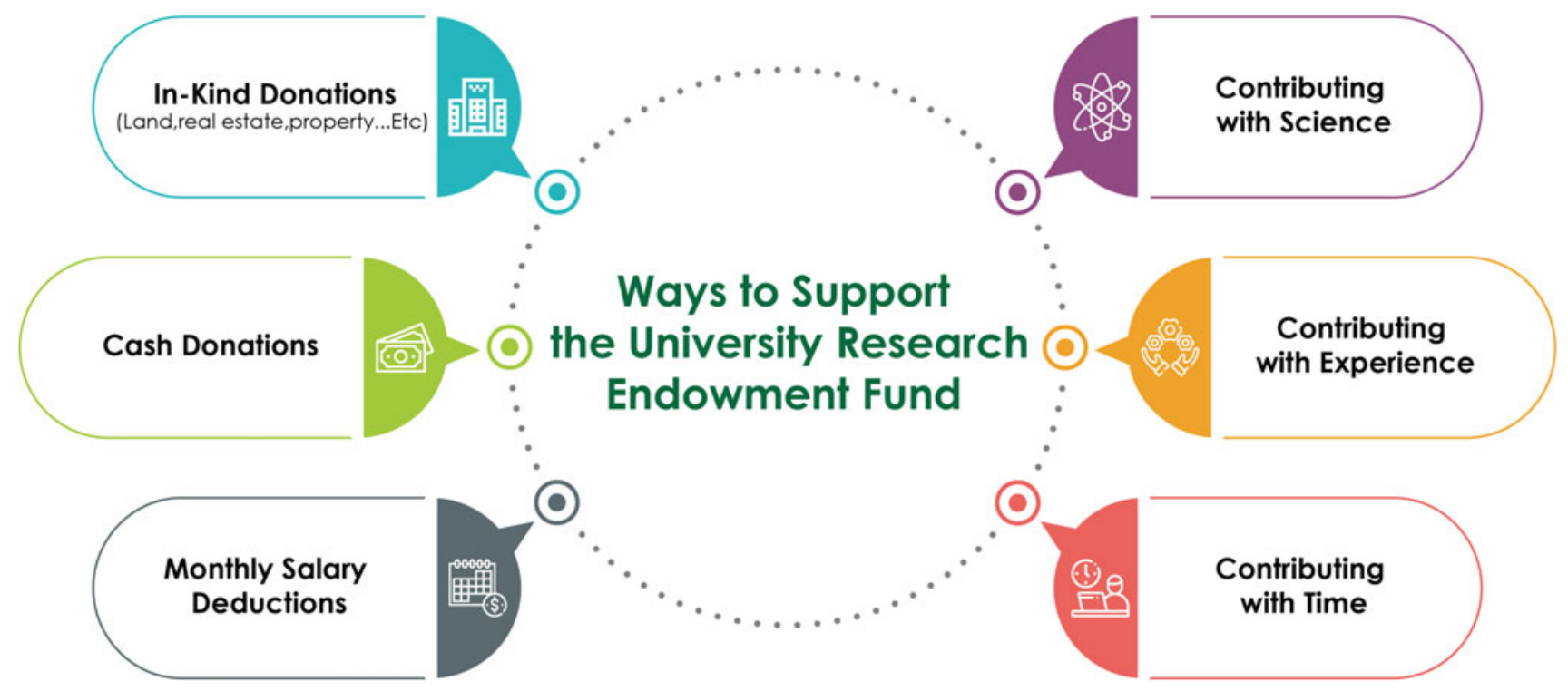

Fig. 4 Ways to support the KAU Research Endowment Fund

\section{Wadi Jeddah Company}

Wadi Jeddah is a closed joint stock company wholly owned by King Abdulaziz University. It was established in 2010, and it is based at the university [11]. It is one of the huge initiatives to raise the university research capabilities and participate in the supervision and investment in the knowledge sectors. Its capital amounts to 27 million US dollars, and it has the right to use a land of 510 thousand square meters for the company's investment purposes. The company seeks to make use of promising investment opportunities in health sectors, communications technologies, energy and environment. 


\section{The Molecular Imaging Company, I-ONE}

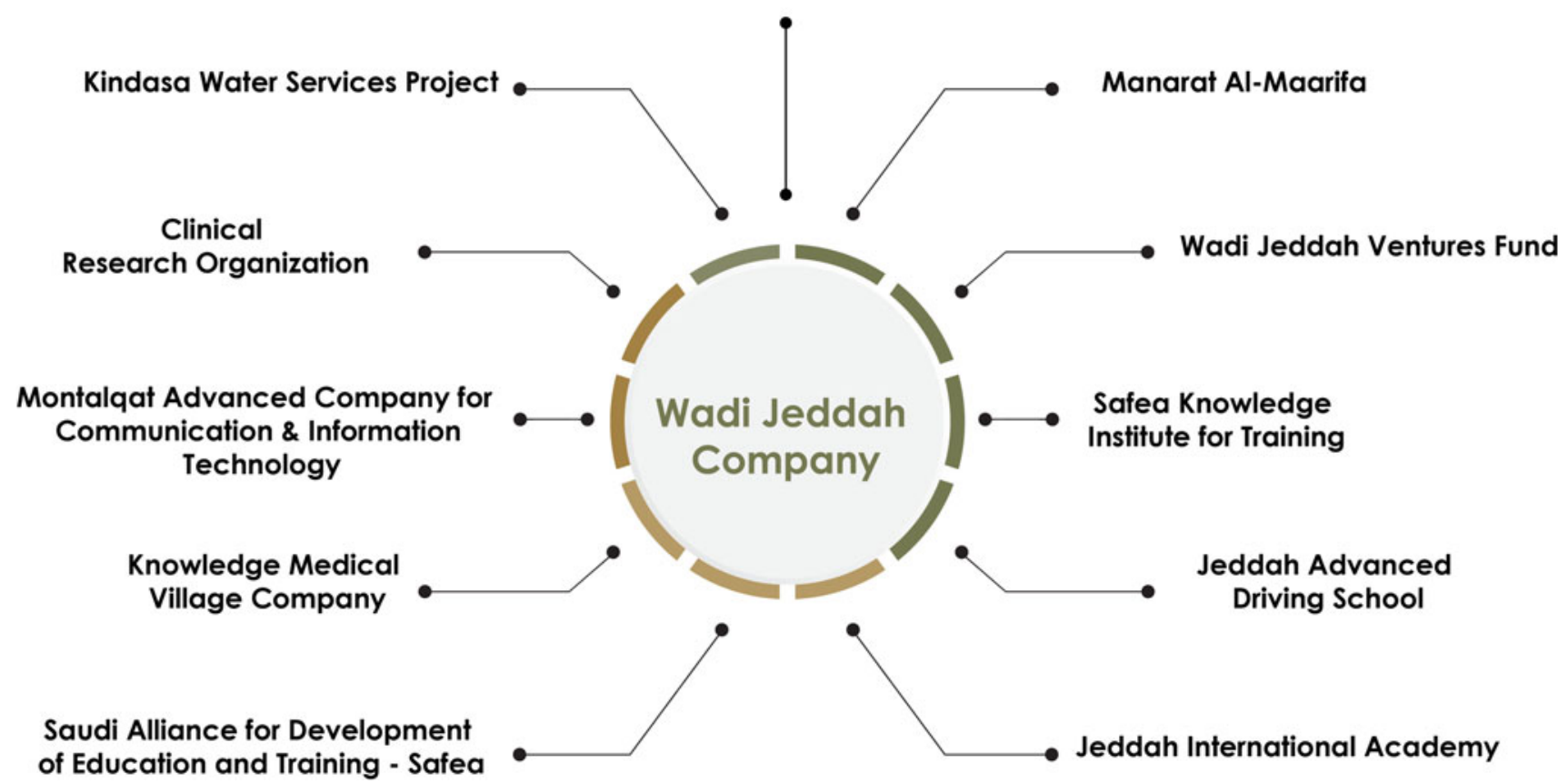

Fig. 5 The companies and investment projects affiliated to Wadi Jeddah Company

The company aims at contributing effectively to the development of a knowledge economy, through partnerships between educational and research institutions and the business and investment community on investment and commercial foundations, by transferring ideas and knowledge to the field of application and transforming them into targeted projects that serve the Kingdom's economy.

The company also seeks to invest in technology transfer and localization, establish business incubators and invest in them, invest patents, intellectual rights, and industrial models; in addition to providing investment opportunities in scientific research and development for faculty, and providing consultations in the field of education development, scientific research and technology industry. The company also seeks to invest in developing allocated lands and available university lands to provide an attractive environment, attract local and foreign investments to participate in supporting the company's goals, and cooperate with bodies, companies and institutions that practice a similar or complementary activity.

KAU has launched four major companies for Wadi Jeddah Company, the first one is (Healthcare sector company, JEDMED), which includes all projects related to healthcare, medical devices, and medical research. The second company is (Energy and environment sector company, JEDPOWER) which covers power generation, agriculture and electricity projects. The third company is (Information technology and communications sector company, JEDTEK), which includes satellite technology and the Internet. The fourth company is (General Investment Company, JEDCAP), which covers all projects that are not included in the tasks of the previous companies, such as the company's land investment projects. Thus, Wadi Jeddah Company is an important contributor to bringing funds to the university in order to carry out its assigned tasks to the fullest.

There are a number of companies and investment projects that are currently affiliated to Wadi Jeddah Company, as shown in Fig. 5.

\subsection{Wadi Jeddah Ventures Fund}

Wadi Jeddah Ventures Fund is a fund for Audacious Investment [12]. It is concerned with investment in startup companies in the establishment phase only (Seed Fund), which is an early phase characterized by a high risk of up to $85 \%$. The Fund aims to invest in companies which use creative and technical work models only, and seeks to achieve two goals: The first is to support starting technical and knowledge industries companies, and the second is to achieve high revenues for the university against high risk. The Fund recently contracted (Tallah), a foreign technology company working in the field of women's cosmetics, and licensed by the General Investment Authority. 


\subsection{Manarat Al-Maarifa}

The Idea of "Manarat Al-Maarifa" (MARED) Real Estate Development project [12] arose to invest a portion of the lands of Wadi Jeddah Company (within the university Campus) in line with King Abdulaziz University's vision to be a beacon of knowledge, with integrated structure, a pioneer in development, and an attractive environment to companies and investors. The project consists of a group of buildings that have been completed with a total area of 149,887 square meters, in addition to another project, which is still under study, to build a mall with an area of 224,000 square meters. The project aims at providing a variety of modern smart buildings: medical clinics, engineering offices, hotel towers, administrative offices, and shops. It is expected that (Manarat Al-Maarifa) will become a real landmark and a start towards creating future visions aimed at transforming into a diversified, prosperous economy led by the private sector and a knowledge-based society, while preserving Islamic values and cultural heritage of the Kingdom.

\subsection{Kindasa Water Services Project}

The Kindasa Water Services project [12] consists of a water desalination plant in King Abdulaziz University branch in Rabigh on an area of 210,000 square meters, for the purpose of producing high-quality desalinated water, to provide the university with its water needs, then commercially investing the surplus water by supplying it to the industrial sector and residential complexes in the city of Rabigh. The project consists of a water desalination plant with all its annexes, including a desalinated water distribution station to meet the needs of the city of Rabigh, a water bottling plant, and a water tank with a capacity of 36,000 cubic meters. The project also includes a research center for water desalination, which contains a mini station with a production capacity of $3.50 \mathrm{~m}^{3}$ per day for the purpose of study and research, supervised by the Center of Excellence in Water Research at the university. The entire project is intended to achieve an investment for the university through Wadi Jeddah Company, in accordance with the strategic plan of KAU, as it contributes to supporting water research, especially in choosing a high-quality technology in the production of desalinated water at low cost, which is the technology of the future.

\subsection{The Molecular Imaging Company, I-ONE}

The Molecular Imaging Company (I-ONE) [13] for the production of radioisotopes and molecular tomography, is one of Wadi Jeddah companies it was established in cooperation with General Electric, which is now one of the world's leading companies in medical care and providing the latest technologies related to investing in knowledge economy. The company works in cooperation with the Italian company ITEL, one of the leading companies in the field of manufacturing radioactive materials and managing modern medical facilities, to manage the radioisotope production division of the company, and to provide the expertise and efficiency necessary to achieve the company objectives. Its objectives include: producing radioisotopes and developing the production of modern radioactive materials using high technology, providing an appropriate environment for conducting new scientific research for the sake of knowledge and economic returns, and providing the global means and capabilities necessary to diagnose the largest number of patients with cancerous tumors. According to international manufacturing standards, the Molecular Imaging Company is unique in the western region in the Kingdom of Saudi Arabia, and produces radioisotopes using the cyclotron in the injection of patients. The company also works on meeting the growing needs of the diagnosis and early detection of cancerous tumors through positron emission tomography.

\subsection{Montalqat Advanced Company for Communication and Information Technology}

Montalqat Advanced Company for Communication \& Information Technology, Mac Tec [14] is a company specialized in the field of information technology. Its most prominent works include the development and creation of an innovative product for managing media screens through a central network. The company is currently working on patenting the product to its name. This is in addition to its work on developing an enterprise resource planning system (ERP) targeting small and medium-sized enterprises. Work on designing and equipping an infrastructure specialized in investing in big data and analysing it, is currently underway, in addition to its technical supplies and projects supported by agreements with international companies in the field of information technology in order to be able to develop integral solutions that contribute to enhancing information technology industry with regard to local products, and providing a suitable environment for attracting investment in knowledge economy, in addition to reducing the leakage rate of revenues of information technology industry to foreign countries. The company's objectives include: establishing profit associative economy platforms, providing the best of developed technical services and solutions in an innovative work environment, presenting products in providing and developing technology solutions, keeping abreast of the 
latest technological developments, innovations and labor market developments, and providing pioneering solutions for information technology services in the Kingdom of Saudi Arabia.

\subsection{Clinical Research Organization (CRO)}

Clinical Research Organization, CRO, [15] is a company registered with the Saudi Food and Drug Authority and the Ministry of Commerce. The company aspires to enter the world map in the field of clinical research by concluding partnerships with international establishments and educational institutes specialized in this field on one hand, and partnerships with international clinical research companies, on the other. The company submitted a request to the Food and Drug Authority to establish a Center for Bioequivalence Studies.

The company's objectives include: conducting clinical research and experiments, establishing the Saudi network for clinical research, and developing and implementing training programs in the field of clinical research and good clinical practice. The company also seeks to achieve the highest revenue on the investment based on its activities.

\subsection{Knowledge Medical Village Company}

The Knowledge Medical Village Company (JED MED) [15] is a complex consisting of a general hospital and a 4-star hotel, on KAU campus in Abhur, on a land area of 22 thousand square meters, through which the university seeks to present an integral model which provides distinguished services in line with most recent technological means in the fields of healthcare and hotels. It has a hospital, a medical rehabilitation center, a physiotherapy center, a health club, and a hotel of international specifications, located north of Jeddah in a distinguished area in Abhur bay overlooking the Red Sea, and when it is completed it will be a prominent landmark in the city of Jeddah. An agreement has been signed with an international hospital (InterHealth Canada) to operate the hospital, and another agreement has been signed with Rotana International Company to operate the hotel.

\subsection{Saudi Alliance for Development of Education and Training-Safea}

The Saudi Alliance for Development of Education and Training, Safea, [16] is an alliance specialized in the development of education and training. The idea of its establishment arose out of the Kingdom of Saudi Arabia's aiming towards knowledge investment and education development, and King Abdulaziz University's striving to contribute to improving education and training, given their importance in helping people improve their professional and academic conditions (Safea) has assumed the responsibility of ensuring good selection of the various programs offered to students, employees, and companies, through cooperation and partnership with expertise houses and international organizations in the field of education and training, in addition to transfering of the latest educational systems and best global practices, followed by their localization in accordance with the social and cultural values of the Kingdom, to promote and develop education and training and improve their outputs. The most prominent projects of (Safea) include: (Jeddah International Academy), (Jeddah Advanced Driving School), and (Safea Knowledge Institute for Training), which will be examined later.

\subsection{Jeddah International Academy}

Jeddah International Academy [17] is a group of private, for-profit schools located within the Al-Faisaliah campus at KAU, and licensed by the Ministry of Education, with departments for boys and girls. It provides general sub-university education, starting with kindergarten, according to the SABIS global curriculum while adhering to the tolerant Islamic perspective. The Academy relies on the use of modern technology that enhances every aspect of school life for students to enhance their academic success, starting with modern interactive blackboards used in the classroom and even electronic books, a computerized testing and learning center and a SABIS digital platform that allows students and parents to access details about their school performance. The SABIS curriculum enhances the ability and desire to learn throughout life, civic and moral values, as well as maintaining high levels of efficiency and quality in educational and pedagogical outcomes. KAU has established this academy to provide world-class advanced general sub-university education, which qualifies male and female students to join world class universities (whether Saudi or international).

KAU has constructed the building of the academy, and a contract has been signed with an international company to operate it as an international school, independently of KAU administration. Developing the love for innovation in the minds of male and female students is one of the most important things offered by the academy. It is committed to providing education with entertainment that enables students to achieve their highest educational goals through self-reliance. It also directs them to academic and personal development through a comprehensive and motivational program. The academy also explores the areas through which each student can demonstrate his/her talents, creativity and achieve his/her desired goals. 


\subsection{Jeddah Advanced Driving School}

A memo of understanding has been signed between King Abdulaziz University and the General Traffic Department to establish a vehicle driving teaching school within the university premises in accordance with the international specifications and standards. Accordingly, the Saudi Alliance Company for Development of Education and Training "SAFEA" has started to establish the school that has been named (Jeddah Advanced Driving School) [18], in a joint investment project with KAU. This is one of the most promising projects due to the great demand for the services of this school. So far, three driving training fields have been established, and three other fields are under construction. The school offers: simulation driving training, field driving training, electronic driving training, and theoretical driving training. The school seeks to improve the efficiency of driving vehicles by applying the best international experiences and practices to enhance road safety and security.

\subsection{SAFEA Knowledge Institute for Training}

Safea Knowledge Institute for Training (SKI, SKInst) is an institute approved by Technical and Vocational Training Corporation in the Kingdom of Saudi Arabia and is affiliated to Saudi Alliance Company for Development of Education and Training "Safea", owned by Wadi Jeddah Company. The institute is characterized by a management that has long experience in the field of human resources development, in addition to the specialized academic expertise provided by the university to the institute [21].

\section{Research Excellence Centers}

In a qualitative step to develop the research structure and the outputs of scientific research at King Abdulaziz University, a number of Research Excellence Centers were established at the university. These are highly-equipped advanced research centers, each of which is specialized in an important research field, with the aim of developing technologies for each discipline according to international standards, and providing innovations to serve the industrial, commercial and service community institutions. These centers are characterized by interest in partnership with international research and industrial institutions in areas of mutual interest. These centers were funded upon their establishment by the Ministry of Education for a specific period. After that, they depend on their research to raise the funds necessary for spending on their research and researchers, and they are thus one of the important funding streams for KAU. Research
Excellence Centers are now twenty eight, including four healthcare centers.

\section{Center of Creativity and Entrepreneurship}

With the increase of global and local interest in entrepreneurial activities and encouragement of ambitious ideas and entrepreneurial projects of young people that contribute to the growth of the knowledge economy, King Abdulaziz University has been keen on having a head start in this field, in completion of what it started in its three strategic plans that focus on quality, worldwide fame, sustainability, excellence in scientific research, community service and entrepreneurship. The Saudi Vision 2030 has had a great role in developing this strategic orientation of KAU, which resulted in a remarkable activity in the university affiliates that are interested in nurturing talent, creativity, and supporting ideas, activities, and entrepreneurial projects. This became evident through the establishment of the Center of Creativity and Entrepreneurship [19].

The Center provides an integral model that includes efforts to educate male and female university students about entrepreneurship, support and sponsorship of innovators, incubation of projects that hold a scientific and economic value, and acceleration of the business of startups, through the two arms of the Center, namely, business incubators, and business accelerators, as shown in Fig. 6. The following is an overview of each of them:

\subsection{Business Incubators}

Business Incubators are the supportive environment that stimulates ideas and projects, and through them, the appropriate factors for creativity, innovation and transforming entrepreneurial ideas into successful investment projects that build the knowledge economy in the Kingdom are created. King Abdulaziz University has established business incubators [20] to embrace creative ideas of an investment nature for KAU students and graduates of the university to help them transform their creative ideas into real job opportunities and investment projects, with the aim of forming a generation of entrepreneurs who are able to create job opportunities for others, providing an ideal environment for developing creative projects, and establishing successful institutions that have the ability to survive and continue on their own. KAU provides business incubators with technical and administrative consultations to reach suitable business models, in addition to training those who have creative ideas on product design and target market study, while providing equipped 


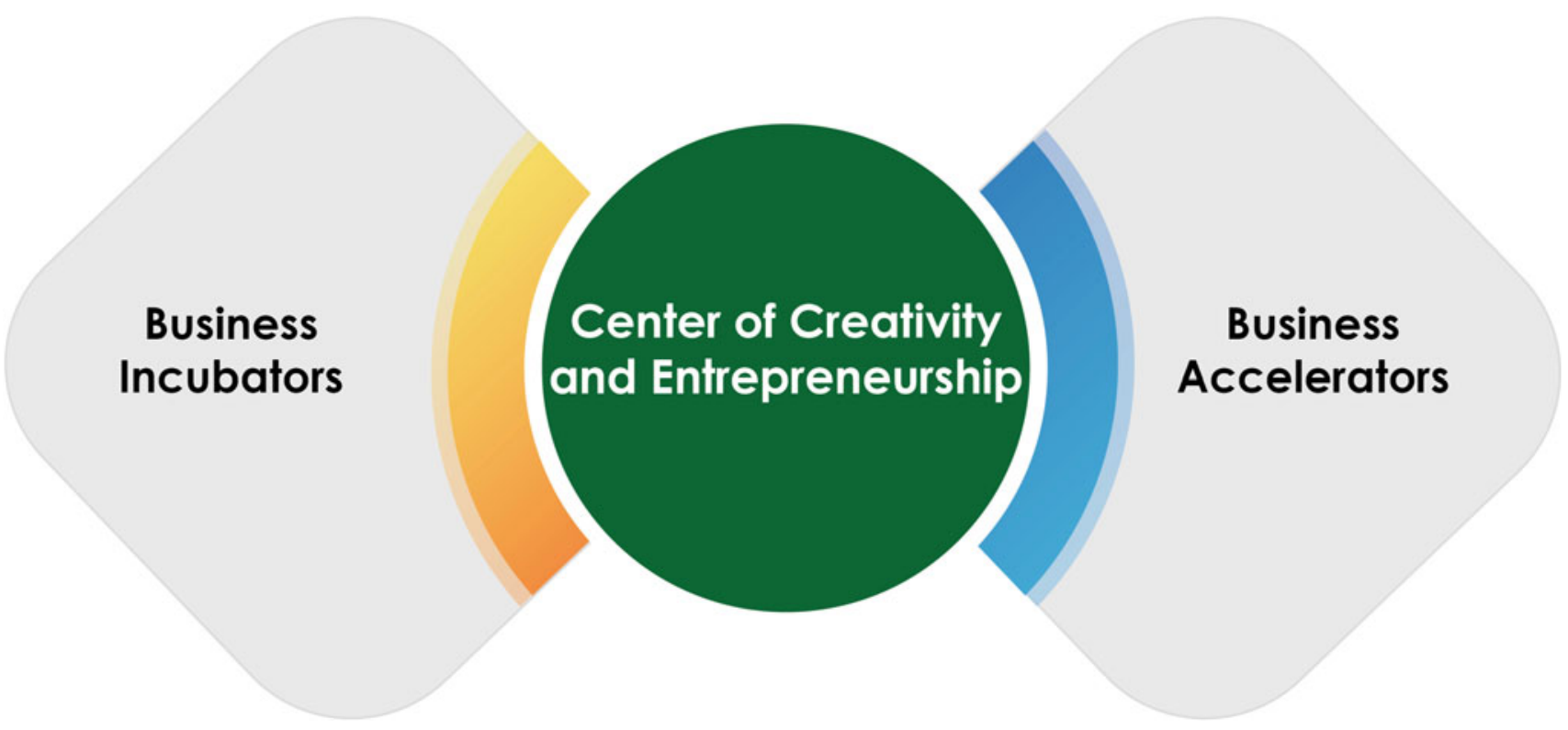

Fig. 6 Units of the Center of Creativity and Entrepreneurship

headquarters for incubated projects, and assisting in building relationships with businessmen and potential clients.

\subsection{Business Accelerators}

Business Accelerators at King Abdulaziz University [21] provide assistance to the university student and graduate entrepreneurs, and to other people who have mature ideas and ambitious projects, and want to transform those ideas and projects into products and companies that can efficiently enter and compete in commercial markets. The Business Accelerators program aims at providing the entrepreneurs participating in it with the knowledge, skills and experiences that help them to establish and operate their projects and companies, providing necessary training, sponsorship, supervision, and support to entrepreneurs at the hands of academically and practically distinguished local and international academics, coaches and experts in the field of entrepreneurship, in addition to spreading the culture of entrepreneurship within the university community and outside it. The accelerator headquarters includes offices for entrepreneurs, and is equipped with modern means of communication and technology, a lab for computer, its programs and technologies, a hall for training and workshops, a theater for lectures, public meetings and shows, accommodating about 130 people, in addition to the availability of wired and wireless internet service, administrative and operational offices, and other facilities and services.

\section{Knowledge Economy and Technology Transfer Center}

King Abdulaziz University is working on directing scientific research to serve the societal needs in various industrial, commercial, educational, economic, environmental and engineering fields in a bid to transfer knowledge and scientific research at KAU to an economic value that contributes to supporting the local economy in policies as well as supporting the university's self resources in the long run. Hence, a need emerged to establish a Knowledge Economy and Technology Transfer Center at KAU to work on communication between the private sector and the university in order to benefit from the outputs of scientific research and patents, with the aim of supporting the transformation of knowledge into an economic value which serves the domestic product, creating new jobs together with enhancing the university's self resources.

The work of Knowledge Economy and Technology Transfer Center [22] is based on the Saudi Vision 2030, the Ministry of Education's Vision, and King Abdulaziz University vision to raise the contribution of small and medium-sized enterprises to the domestic product, promote and support the culture of innovation and knowledge economy, as well as transfer and localize technology. The work of the Center is in line with the strategic objectives of the Ministry of Education and KAU, namely, diversifying the sources of funding for education and partnerships, investing in it, and strengthening local and international partnerships. 
The objectives of the Center are: Transferring the university's scientific research culture to the development trend which serves the societal needs on one hand and acquaints the researchers with manufacturing requirements on the other hand; Turning ideas into economically valuable commercial products; Supporting the talent, creativity and innovation of university researchers; investing the university's scientific research outputs to diversify funding programs and partnerships; Improving ways of communication between the university's scientific research sector and the public and private sectors as well as directing scientific research within the university to serve their needs; Turning ideas and research into products, programs and services that are marketed to the domestic and international market; Forming partnerships to support startups emerging from the university; Spreading the culture of diligence and persistence in order to achieve innovations and patents; Supporting the creative orientation in the society and linking it to the university; Protecting and registering patents locally and internationally; Protecting intellectual property and trademark rights; Marketing patents locally and internationally; Conducting studies of ideas that can be invested in and turned into investment projects; Evaluating ideas in terms of expected investment risks and returns.

\section{Technology Transfer by Marketing the University Research Outputs and Patents}

The Intellectual Property Investment Administration [23] was established to make use of the scientific research outputs: regarding documentation, development and investment, and for King Abdulaziz University to be a pioneer in the number of registered intellectual property and the number of investment projects resulting from the rights of such certified property. King Abdulaziz University has a special unit designed to register patents resulting from the research of faculty and all those working at KAU, including students, with international bodies. In this regard, KAU has spared no effort to help researchers register patents, support them in everything related to this goal, and to market these patents. To this effect, KAU bears all costs of the Law Office and the fees related to patent registration whether in USA, Europe or Japan. Moreover, the university has allocated an award to each inventor upon completion of the patent registration. After obtaining the patent, the inventor(s) is (one) given financial rewards of up to $\$ 8,000$ for patents registered in USA, for example, in order to urge researchers to produce patents so that the university can then invest them to increase its income from scientific research.

\section{Future Projects}

The third strategic plan of King Abdulaziz University, called (TAZIZ) "Enhancement", has a number of objectives which the university pursues in order to diversify its sources of income. For the time being, we will just mention some projects that are still under study: projects of increasing investment returns; activating partnerships and opening investment prospects with big companies; self-operating some university sectors in a commercial investment manner; establishing "Naqaha" Center for advanced health care and health tourism; privatizing some of KAU sectors (e.g. service and research sectors) and making them available for investment for everyone; establishing private training institutes that provide services commercially for everyone; activating on-the-job courses that can be offered to both public and private sectors; expanding online training programs; providing paid diplomas related to employment and that meet the labor market's needs; marketing the expertise and capabilities of the university, its laboratories and research centers; investing the university property (theatres, sports buildings, lands, etc.); rationalizing expenditures and reducing costs; restructuring and re-engineering administrative and financial procedures to achieve idealism; establishing companies for industries concerned with technology transfer and localization; and last but not least: supporting innovation and encouraging patenting (by giving double weight to the patent on publishing the scientific paper in case of promotion application for academics), then investing these patents by converting them into an investment product.

\section{Post-Coronavirus Pandemic University Funding}

Coronavirus disease (COVID-19) is an infectious disease caused by a newly discovered virus from the strain of coronaviruses and had broken out in Wuhan, China in December 2019. It was classified by WHO on March 11, 2020 as a "global pandemic", for the virus can spread directly among people, its infection rate is high and it has spread in most countries of the world. In light of the way and speed of the novel coronavirus outbreak, the governments of countries around the world have taken precautionary measures to reduce infection among their citizens and residents. As a result, the global economy has entered a state of severe recession together with a sudden and severe downturn, which will lead to a deficit in the general budgets of all countries, including the Kingdom.

Therefore, it has become necessary to evaluate and to study the effects of the coronavirus (COVID-19) spread on KAU 
funding at this stage. Coronavirus pandemic has negatively affected the economy, as indicated by economists from different countries around the world. The Kingdom has spared no effort to control this virus, provide health services and civil protection systems for people, and protect the economy from further damage. Given the impact of this pandemic on economic growth, the Kingdom is preparing to use the appropriate tools to achieve suitable growth and protection from further negative risks, within the general framework that provides flexibility to deal with unusual events, such as the coronavirus pandemic, so that additional expenditure is associated with the pandemic. Things are, now, being re-evaluated to determine some financial policies that can be taken to maintain the well-being of citizens and mitigate the negative effects of the coronavirus epidemic. KAU is studying mechanisms to address the economic repercussions related to coronavirus, taking into account special warnings about the economic impact of the pandemic on the Kingdom, including the need to support the health sector and provide financial support to the most affected entities.

All entities in the Kingdom, including King Abdulaziz University, are studying the economic effects of the coronavirus pandemic and the measures to be taken to mitigate the negative economic effects of the pandemic. The measures taken by the Kingdom include postponing the repayment of loans to small- and medium-sized companies for 6 months, while urging the banks to increase loans to the private sector, especially the most affected sectors, in the coming months. The Saudi Arabian Monetary Authority (SAMA) has reduced fees for ATM withdrawals and POS transactions to encourage individuals to switch to online transactions, instead of cash, as a measure that helps curb the spread of the virus caused by the circulation of bank notes.

For its part, King Abdulaziz University considers these measures to be essential, and help face the pressures, make liquidity available, and ease the economic pressure on consumption expenditure. KAU also believes that the impact of the curfew and the precautionary measures taken by health authorities in the Kingdom led to containing the virus and greatly reducing its spread.

Based on the foregoing, spending on education may fall short of the amount included in this year's budget, which means that King Abdulaziz University must find additional alternatives enabling it to address this decrease in the amount of government funding so that it can fulfil its educational and research mission as well as serve the community. KAU has benefited from the precautionary measures applied in the Kingdom, as it was able to shift to e-learning in record time thanks to its previous experience with e-learning and distance education, with an appropriate infrastructure in place, such as the Blackboard program $(\mathrm{Bb})$ used in (Deanship of e-learning and Distance Education) to provide its educational programs for residents of various regions in the
Kingdom. KAU was also able to go "Paperless" through electronic interaction among various departments and organize many awareness-raising events on coronavirus, using the applications available on the internet. Hence, once the pandemic is over, it is expected that KAU will draw on its experiences gained during this pandemic in carrying out a number of scientific and research activities that will enable it to attract additional funding to its budget, such as:

- Providing online courses and making use of the expertise and skills of faculty to offer various training courses benefiting many different members of society.

- Expanding online teaching of some academic programs, and providing educational programs required for the public and private sectors.

- Providing consultations and studies in many fields using the Internet (Online).

- Re-engineering the administrative and financial procedures so that they are all programmed to reduce expenses and achieve idealism.

- Urging faculty and students to build more mobile applications and provide e-solutions to many issues.

\section{Conclusion}

As the Executive Administration of King Abdulaziz University believes in the capabilities of its employees and infrastructure, KAU, through the implementation of its previous strategic plans, has found out that it can take many steps that are believed by many to be impossible. It has also realized that the path ahead is open to achieve its objective through the efforts of all its employees. Achieving much of what it was aiming for drives it to work even harder, as those who want a bright future have to act now. On the other hand, those who do not work hard, become outdated, as happened to many universities that flourished for a period of time then retreated. The government has, commendably, funded KAU for half a century, and it is high time for KAU to think of new sources of funding. Thus, it took the aforementioned actions in this chapter to seriously explore new income resources based on the participation of all those who benefit from higher education, including public and private sectors companies, institutions and organizations, as well as the local community.

It can be said that KAU has relied on main ideas in developing its financial resources, all of which are in line with what is expected of international universities in education, scientific research and community service. Such ideas include research endowment; establishing an investment arm for the university, i.e. Wadi Jeddah Company; in addition to providing consultations and research to the 
public and private sectors through the Research and Consulting Institute; marketing its research products and inventions by transferring technology; encouraging creativity and entrepreneurship; making its research centers available to solve community problems; and providing its services to the community through diplomas in the specializations required in the labor market. This is in addition to the things it considers doing or expanding in the near future, as part of its current strategic plan called (TAZIZ) "Enhancement", as a result of coronavirus pandemic effects on the economies of countries, including the Kingdom, as part of using e-learning methods, or as part of shifting to a paperless university style in educational and administrative matters through electronic interaction among all university sectors.

Since the journey of a thousand miles begins with a single step, King Abdulaziz University has taken this step with the hope of ranking among international universities in the field of diversification of sources of funding and multiple areas of income.

\section{References}

1. http://www.shanghairanking.com/ARWU2019.html

2. https://www.timeshighereducation.com/world-university-rankings/ 2020/world-ranking\#!/page/0/length/25/sort_by/rank/sort_order/ asc/cols/stats

3. https://www.topuniversities.com/university-rankings/worlduniversity-rankings/2020

4. https://vision2030.gov.sa/en

5. https://laws.boe.gov.sa/BoeLaws/Laws/LawDetails/8ee742827f0d-49ff-b6ee-aafc00a3d801/1

6. https://vpbkc-im.kau.edu.sa/Default-110-EN

7. https://self-resources.kau.edu.sa/Default-496-EN

8. https://community.kau.edu.sa/Default-185-EN

9. https://communityserviceskau.com/tedxkau-2020/

10. https://www.ted.com/

11. https://raci.kau.edu.sa/Default-195-EN

12. https://www.wadi-jeddah.com.sa/en/home/

13. https://www.wadi-jeddah.com.sa/investments/\#wj-ventures

14. http://www.ione.com.sa/

15. https://wj-mactech.com/en/home/

16. https://www.kau-med.com/

17. http://www.wj-safea.com/en/\#

18. https://jia.sabis.net/

19. https://jeddahds.com.sa/

20. https://www.facebook.com/pg/SKInst/posts/

21. https://gcpc.kau.edu.sa/Default-216-EN

22. https://gcpc.kau.edu.sa/Pages-kauBI.aspx

23. https://gcpc.kau.edu.sa/Pages-KAUMU.aspx

24. https://kett.kau.edu.sa/Default-416-EN

25. https://www.kau.edu.sa/Default-7010-EN
Abdulrahman Obaid Al-Youbi is the President of King Abdulaziz University (KAU) and the President of the International Advisory Board (IAB) of KAU since 2016. He is a Professor of Chemistry at KAU since 2000. He earned a Ph.D. in Physical Chemistry from Essex University, UK in 1986. Throughout his career, Prof. Al-Youbi is an active researcher in his specialization, a passionate teacher, an academic and administrator. $\mathrm{He}$ participated in many research projects and published more than 150 papers in ranked scientific journals. He also supervised many graduate students. He has held a variety of Academic Administrative positions at KAU such as: In (2015-2016), he was Acting President of both KAU and Jeddah University, Vice President for Academic Affairs (2009-2016), Vice President (20022009), Dean of the Faculty of Science (1999-2002), Vice-Dean of the Faculty of Science (1992-1999), and Chairman of the Chemistry Department. As President of KAU, Prof. Al-Youbi has devoted his position to strengthen excellence in academics and research with a dedication to develop an innovative culture. Through President Al-Youbi's leadership, KAU has remained the top university, not only in Kingdom of Saudi Arabia, but also in the Arab World. His current focus is on expanding KAU's leadership by continuing to build on its long-standing strengths in education, research, entrepreneurship and Community Service to the people of Kingdom of Saudi Arabia. President Al-Youbi participated in more than eighty committees, boards, teams and working groups at KAU as well as at Saudi Ministry of Education level. In particular, he has participated in the committees that have established new universities in the Kingdom, (Taiba University, Jazan University, Tabuk University, and the Northern Border University). He has also attended many scientific conferences in the Kingdom and abroad. In addition to his membership in the first formation of the University Affairs Council in the Kingdom of Saudi Arabia.

Adnan Hamza Mohammad Zahed is Consultant to the President of King Abdulaziz University (KAU) since 2016 and the Secretary-General of the International Advisory Board (IAB) of KAU since 2010. He was the KAU Vice President for Graduate Studies and Scientific Research (2009-2016), and worked before that as Dean of Graduate Studies (2007-2009), and before that, he was Vice Dean of the Faculty of Engineering (1997-2007). Prof. Zahed is a full professor in the Chemical Engineering Department at KAU since 1996. He also worked in the industry sector as General Supervisor (Consultant) in Saudi Badrah Company (Jeddah, KSA, 19951996), Deputy General Manager at Savola Food Company in Jeddah (19931995), and Deputy CEO of Tasali Company (Jeddah). He holds a B.Sc. in Chemical Engineering from King Fahd University of Petroleum and Minerals, KSA (1976), and a M.S (1979) and Ph.D. in Chemical Engineering from University of California (Davis), USA (1982). He published eleven books most of them in higher education, and more than 60 papers in international conferences and refereed journals, in addition to one patent and more than 75 technical reports written for many bodies of Saudi community. He also participated as a co-author of several University Guides such as the Graduate Studies Guide, Applicable Theses Guide, Thesis Writing Guide, Graduate Studies Procedure Guide, Faculty of Engineering Prospectus and Annual Report of Research Activities in Faculty of Engineering. Prof. Zahed was included in Marquis (Who's Who in the World 2006). He participated in four academic accreditation meetings in USA, and in more than 25 local and international conferences, symposia and forums. Prof. Zahed visited a number of distinguished American, European and Asian universities as a delegate of the Saudi Ministry of Education. 
Open Access This chapter is licensed under the terms of the Creative Commons Attribution 4.0 International License (http://creativecommons. org/licenses/by/4.0/), which permits use, sharing, adaptation, distribution and reproduction in any medium or format, as long as you give appropriate credit to the original author(s) and the source, provide a link to the Creative Commons license and indicate if changes were made.

The images or other third party material in this chapter are included in the chapter's Creative Commons license, unless indicated otherwise in a credit line to the material. If material is not included in the chapter's Creative Commons license and your intended use is not permitted by statutory regulation or exceeds the permitted use, you will need to obtain permission directly from the copyright holder. 